\title{
Introduced parasitic wasps could control glassy-winged sharpshooter
}

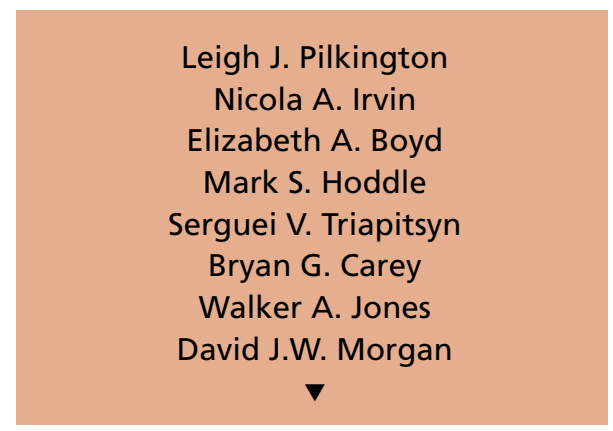

The glassy-winged sharpshooter (GWSS) is an introduced pest that spreads the bacterium Xylella fastidiosa, which causes a variety of diseases such as Pierce's disease in grapevines and leaf scorch in oleanders. GWSS has been established in Southern California since about 1990 and has also successfully invaded French Polynesia, Hawaii and Easter Island. Researchers from UC, the U.S. Department of Agriculture and the California Department of Food and Agriculture have introduced parasitic wasps for the biological control of GWSS. Four parasitoids from the southeastern United States have been released and appear to be establishing in Southern California. Parasitoids from Argentina are also being evaluated in quarantine but have not yet been released.

The glassy-winged sharpshooter southeastern United States that has become extremely pestiferous in Southern California, where it became established around 1990 (Sorensen and Gill 1996), possibly imported as eggs on nursery or private plant material. GWSS (Homalodisca coagulata Say [Homoptera: Cicadellidae]) is now widely established in several Southern California counties (CDFA 2003) (fig. 1, page 224), and successfully invaded Tahiti in 1999 (Cheou 2002), Hawaii in 2004 (Hoover 2004) and Easter Island in 2005. ${ }^{*}$ The insect's population growth in California has been extraordinary, facilitated by a lack

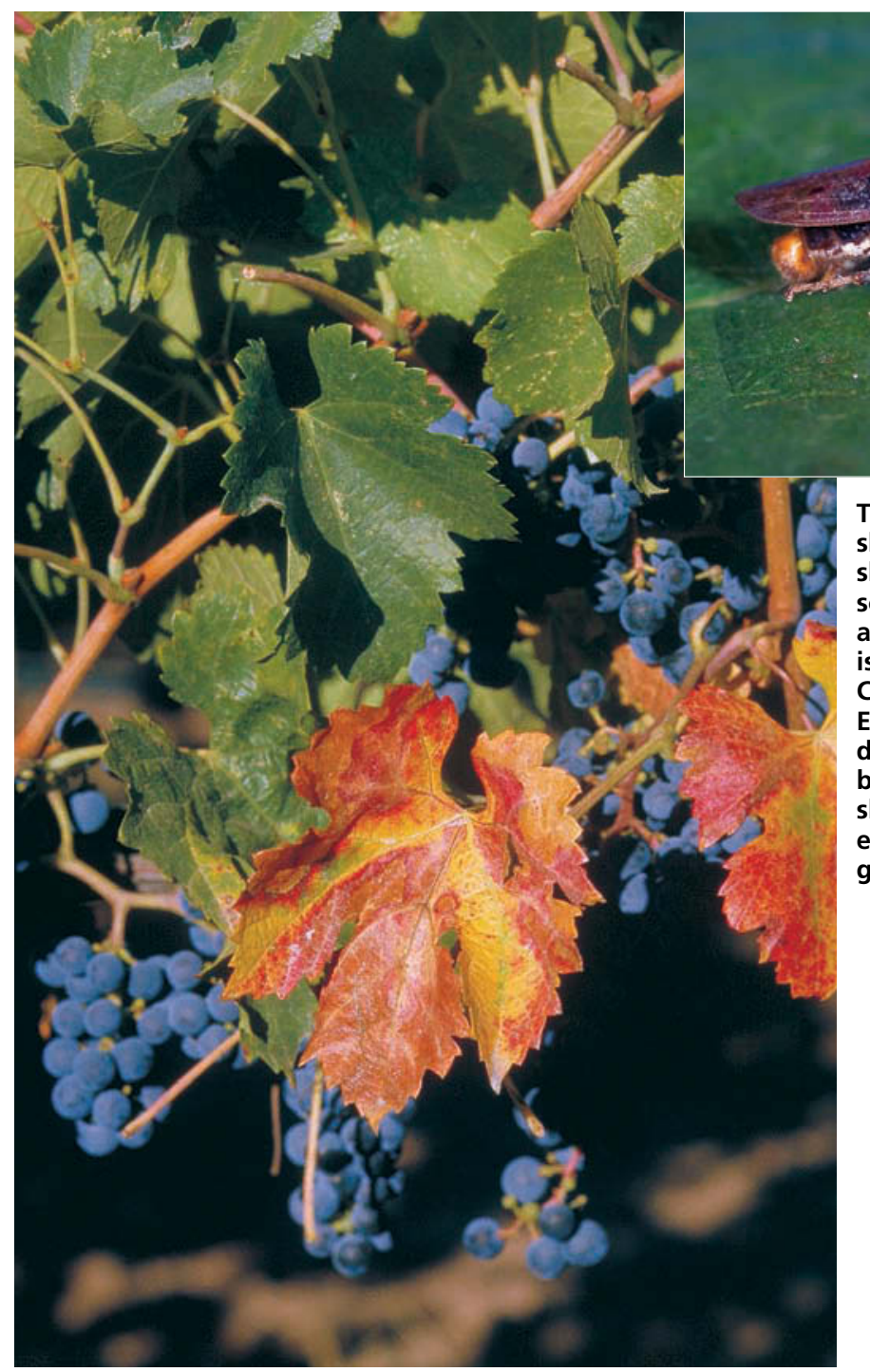

of coevolved natural enemies, coupled with the irrigation of agricultural and urban areas in desert habitats that would otherwise be too dry to support GWSS populations (Hoddle 2004a).

The GWSS feeds exclusively on xylem fluids, and its ability to spread the xylem-dwelling plant pathogenic bacterium Xylella fastidiosa is at the core of its classification as a pest in California. In California, the GWSS-X. fastidiosa combination causes Pierce's disease in grapes, almond leaf scorch, alfalfa dwarf disease and oleander leaf scorch. In addition, the number and type of plant maladies caused by GWSSvectored $X$. fastidiosa is likely to in- crease. Already the bacterium has been found to cause two previously unrecognized diseases in olive trees and liquidambar, where it causes scorchlike symptoms. The GWSS-Xylella combination has devastated or has the potential to devastate many agricultural crops, native vegetation, and urban ornamental and landscape plants. The potential effect of GWSS vectoring $X$. fastidiosa into native California vegetation that previously had no association with the bacterium may lead to new epidemics, and so is particularly worrisome. Consequently, the establishment of GWSS in California has irrevocably changed the ecology of X. fastidiosa in 


\section{GWSS has shown strong invasive potential, having become established in a variety of places outside its native range, including California, French Polynesia, Easter Island and Hawaii.}

California's wilderness, agricultural and urban landscapes.

The presence of Xylella in Tahiti and Hawaii is currently unknown. It is possible that the bacterium was introduced to these South Pacific islands via the importation of ornamental plants from areas in the Americas where Xylella is native. These ornamental plants could be silent Xylella reservoirs that harbor the bacteria without expressing disease symptoms. However, once a vector such as GWSS arrives, they could transmit the bacteria to susceptible host plants.

\section{Economic impact of GWSS}

The economic costs to California attributed to GWSS are immense. For example, oleander leaf scorch has caused damage in excess of an estimated $\$ 52$ million on 2,000 miles of freeway median plantings (Costa et al. 2000). In 1998 and 1999 grape growers in Riverside and San Diego counties accrued estimated losses of $\$ 37.9$ million due to Pierce's disease (Siebert 2001). In 2000 , researchers in cooperation with affected grape and citrus growers spent $\$ 6.9$ million to apply spray applications of Admire and Assail (acetamiprid) directly on GWSS habitat in Temecula and Bakersfield, in an effort to manage populations migrating into vineyards. In 2002, primary producers incurred additional economic costs resulting from GWSS containment activities such as inspections of export nursery stock and shipments of bulk grapes and citrus from GWSS-infested counties (CDFA 2003). There are currently more than 70 state and federal research programs studying GWSS or X. fastidiosa.

Traditional pesticide use and cultural practices to assist in reducing the populations of GWSS may be augmented by a long-term and cost-effective use of biological control, an area heavily researched in California with a history of success.

\section{Biological control strategies}

Classical biological-control strategies to reduce GWSS populations in California are being pursued by researchers at UC Riverside, the U.S. Department of Agriculture's Agricultural Research Service (USDAARS) and the California Department of Food and Agriculture (CDFA). Biological control involves identifying natural enemies of the target pest. After the control agent is deemed safe and cleared from secure quarantine facilities, they are released into the environment, where they utilize the pest as food and thereby regulate its population growth and subsequent abundance.

In the southeastern United States and northeastern Mexico, GWSS eggs are parasitized by several species of mymarid and trichogrammatid parasitic wasps. The most common natural enemies associated with GWSS eggs in the southeastern United States are all mymarid wasps: Gonatocerus ashmeadi Girault, G. triguttatus Girault, G. morrilli Howard and G. fasciatus Girault (Triapitsyn and Phillips 2000). In the late 1990s, in an effort to use natural enemies to control GWSS populations in Southern California, UC and CDFA imported these four parasitoids from southeastern states, cleared them through quarantine and introduced them into California urban and agricultural areas.

G. triguttatus was first released in fall 2000 in Riverside, Ventura and Kern counties. G. ashmeadi and G. morrilli releases started in 2001, and G. fasciatus in 2002. Anagrus epos (from Minnesota) releases started in 2005. Over 1.2 million parasitoids have now been released in 13 California counties where GWSS populations have been reported. More than 1,900 releases have been made at 373 release sites covering agricultural, riparian and urban environments (see CDFA [2005] for release locations).

Two of these species (G. morrilli and G. ashmeadi) are already established in California. G. morrilli is native to California and G. ashmeadi is self-introduced from the southeastern United States (with no direct assis-

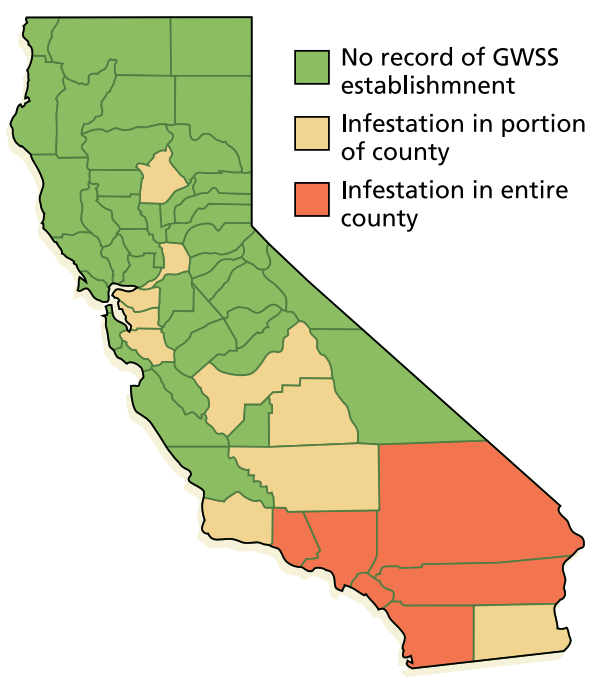

Fig. 1. GWSS establishment in California counties and infested parts of counties.

tance from human intervention). While G. ashmeadi may have established on early GWSS populations, it more likely established on the native smoke-tree sharpshooter (Homalodisca liturata Ball) (Vickerman et al. 2004).

While these two species were already established, additional introductions of the same species may be more effective. For example, the introduced southeastern parasitoid populations may exhibit a greater ability to tolerate cool winter temperatures and dry conditions, or be more aggressive reproductively. These characteristics could help the parasitoids become established and make them more effective as control agents. The new parasitoid stock will likely increase the genetic variability of the already established G. morrilli and G. ashmeadi populations, which could lead to improved biological control.

CDFA has also made more than 90 separate recoveries of egg masses parasitized by G. triguttatus or G. fasciatus at 23 sites in seven Californian counties, suggesting that these control agents are becoming established.

Biological control is a long-term strategy for the suppression of GWSS in areas where it has already become established. To this end, CDFA has established two facilities based in Riverside and Kern counties to mass produce, release and monitor introduced biological control agents. 

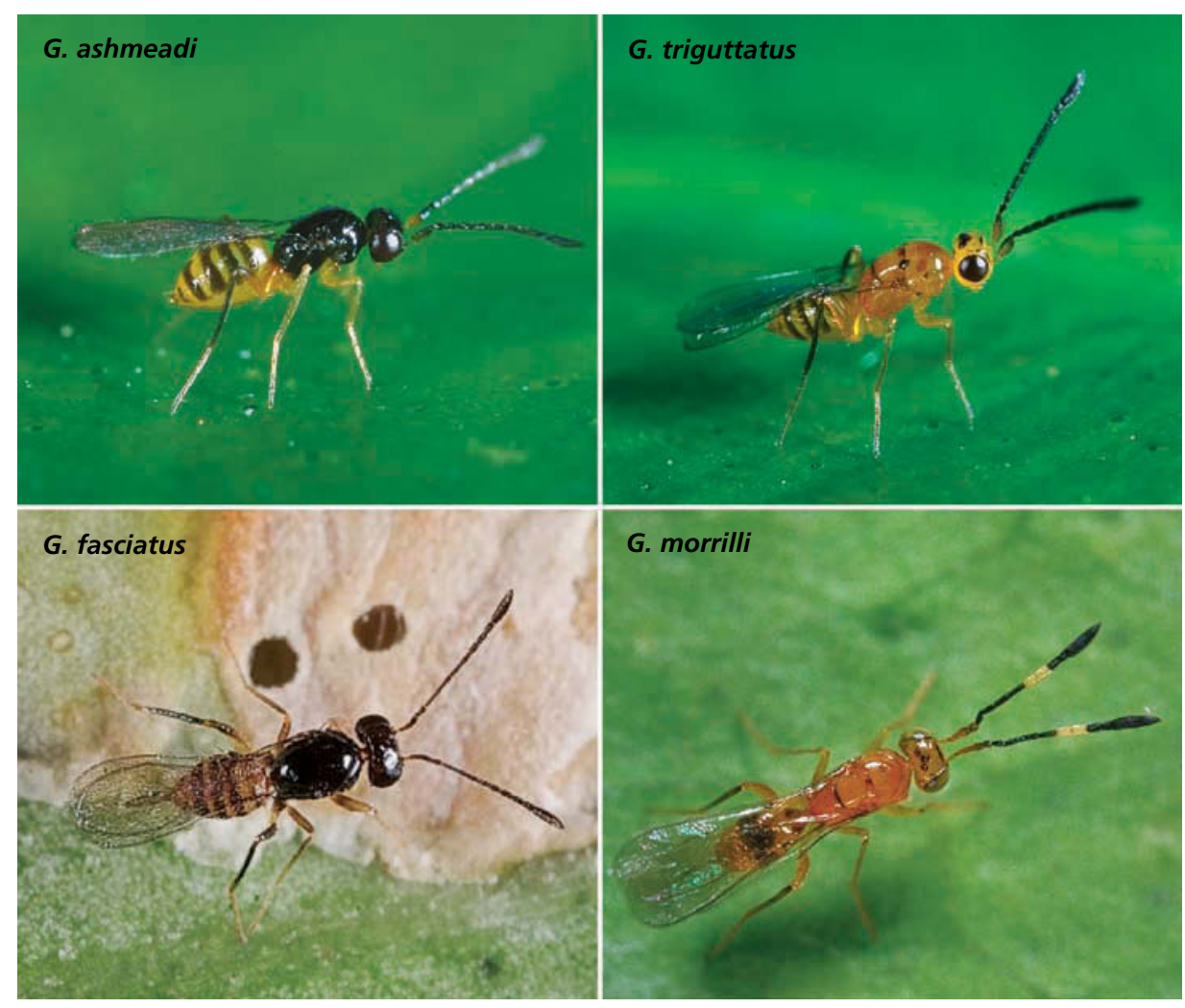

G. morrilli

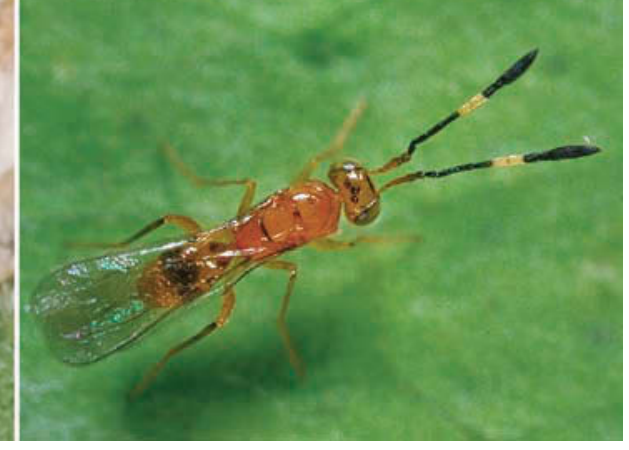

USDA-ARS and CDFA have also been evaluating the safety of mymarid parasitoids imported from Argentina for possible use against GWSS in California. Quarantine work at UC Riverside indicates that Argentinean parasitoids will readily attack GWSS even though they did not evolve in the native range of GWSS. These evaluations are ongoing and no releases have been made.

\section{Nontarget impact of parasitoids}

Biological control has come under increased scrutiny because there is some evidence that under certain circumstances natural enemies released for the control of a pest species may attack nontarget species and adversely affect the populations of these organisms (Hoddle 2004b). To minimize such unwanted environmental effects, UC Riverside scientists have studied native sharpshooters to see if they are vulnerable to attack by parasitoids native to the southeastern United States, northeastern Mexico and Argentina. While none of these native sharpshooters is beneficial in the sense that they predate or parasitize insect pests, their demise would likely trigger a cascade of nutritional effects that could adversely affect other native spe- cies and the food web on which they all depend.

UC and CDFA scientists screened all introduced GWSS biological conize closely related nontarget species of Homoptera found in the area of introduction. These include the southeastern species $H$. insolita (Walker) and the southwestern species H. liturata (both Proconiine sharpshooters); three sharpshooters of the Cicadellini tribe, Colladonus montanus (Van Duzee) (Cherry mountain leafhopper), (blue-green sharpshooter) and Xyphon fulgida (Nottingham) (red-headed sharpshooter); and other species of leafhoppers from a different subfamily, Euscelidius variegatus (Kirschbaum), and Macrosteles fascifrons (Stål) (Aster leafhopper). To date, the only nontarget species susceptible to the introduced agents, as determined by UC Riverside scientists, is H. liturata, a species that is implicated in X. fastidiosa transmission in agriculture in California and the southwestern United States, but that exists primarily in desert habitats where parasitism by introduced mymarid wasps is often low. The susceptible $H$. liturata is from the same tribe trol agents for their ability to parasitGraphocephala atropunctata (Signoret)
4 Parasitoids can aid in control of the glassywinged sharpshooter. Clockwise, from upper left: Gonatocerus ashmeadi is widespread in California and was most likely self-introduced from the southeastern United States and northeastern Mexico; G. triguttatus is a subtropical and tropical species introduced into California from Mexico and southeastern Texas; G. morrilli, native to Southern California, is having its genetic pool augmented with conspecifics collected from other U.S. regions; G. fasciatus is native to the southeast and Midwest and has gregarious reproductive habits.

(Proconiini) and genus (Homalodisca) as GWSS, and is similar to the GWSS in its egg-laying and generalist plant-feeding habits. As such, it is expected to be utilized by introduced Gonatocerus spp.

Scientists at UC Riverside are investigating three other common native sharpshooters (Cicadellinae). Preliminary observations have revealed that the GWSS parasitoids may affect their populations. However, the habitats occupied by these common native sharpshooters have less overlap with the GWSS, and they are from different tribes. The habitats of the Cicadelline sharpshooters (X. fulgida) and the green sharpshooter (Draeculocephala minerva Ball) both consist of grasses such as Bermuda and Johnson grass (Cynodon dactylon [L.] and Sorghum halapense [L.] respectively), making them improbable hosts for Gonatocerus spp. The bluegreen sharpshooter (G. atropunctata), also of the Cicadellini tribe, prefers humid, partially shaded and densely vegetated habitats. This sharpshooter is often found in coastal or riparian habitats consisting of trees, vines and succulent shrubs. These unlikely foraging areas, combined with the differing tribal origins of the sharpshooter and the absence of any records indicating Gonatocerus emergence from any egg masses may make this sharpshooter an improbable alternate host for the three Gonatocerus parasitoids.

Additionally, sticky-card traps in the Southern California habitats occupied by G. atropunctata have yielded no capture of the widespread and established parasitoid G. ashmeadi (Boyd, unpublished data). Native sharpshooter eggs are approximately one-half the size 


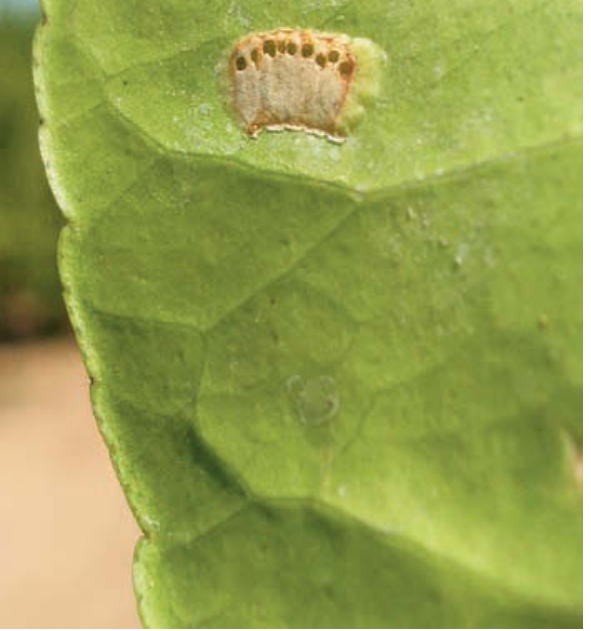

Parasitoid exit holes on a citrus leaf indicate that adults successfully chewed through the egg casing and leaf epidermis to emerge.

of GWSS eggs, are laid singly, and are embedded into the stem material rather than in groups just below the epidermal layer as is characteristic of GWSS egg masses (Boyd, unpublished data). These characteristics, coupled with the different taxonomic placement, make the blue-green sharpshooter an unlikely host for any of the GWSS parasitoids.

\section{GWSS and natural enemies}

UC Riverside scientists working in Southern California and USDA scientists working in eastern Texas collected phenological data on GWSS and G. ashmeadi populations for 2 years. (Phenological data is information on populations with relation to the climate and time of year.) In Southern California, GWSS exhibits two distinct population peaks (fig. 2), the first in the spring when an average of $12 \%$ of GWSS eggs were parasitized, and the second in the summer when an average of $19 \%$ of eggs were parasitized. This summer figure contrasts with reported parasitism rates of up to $100 \%$ in some regions, such as Florida (Triapitsyn and Phillips 2000). A possible explanation for this discrepancy in parasitism is that data being collected are "snapshots" from any given season. For example, the data collected from citrus grown at UC Riverside Agricultural Operations often reflects nearly $100 \%$ parasitism rates in individual sampling events, but this level of oviposition is generally associated with low GWSS egg numbers

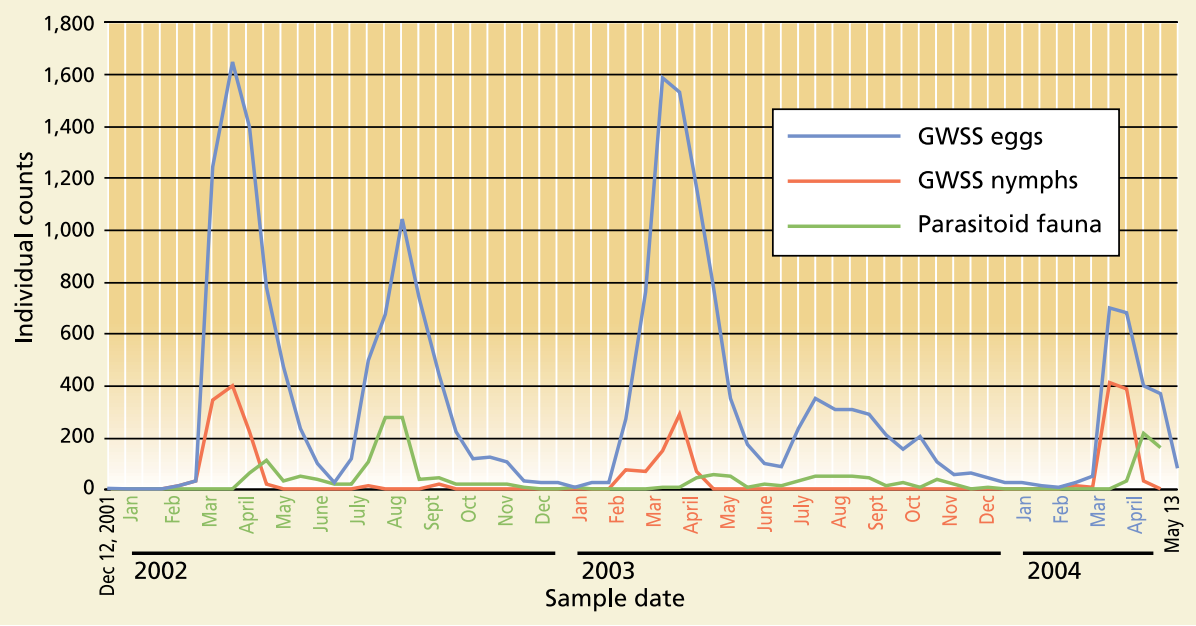

Fig. 2. Population data on GWSS nymphs, adults and parasitoids gathered from citrus orchards at UC Riverside. This information is invaluable in assisting our understanding of pest and natural enemy phenology and population abundance over time.

and is not reflected in the overall mean parasitism rates for any one season. Of the sharpshooter egg masses surveyed in Riverside, $17 \%$ had at least one egg parasitized by Gonatocerus spp. in the spring, compared to $30 \%$ in the summer.

In Weslaco, Texas, USDA researchers observed summer parasitism rates ranging from $38 \%$ to $100 \%$ of discovered GWSS egg masses with at least one egg parasitized (G. triguttatus is the key natural enemy in this area). The Texas data demonstrates that GWSS populations might be successfully suppressed if efficacious egg parasitoids are successfully established in California. However, given that GWSS is such an effective vector of the $X$. fastidiosa pathogen, even highly successful suppression of GWSS may lead to populations that remain above acceptable levels for vineyard managers. Regional lowering of GWSS populations will, however, assist greatly in all control efforts and management programs to curtail its spread in agriculture and the urban environment.

\section{Parasitoid biology}

Mymarid wasp parasitoids that attack GWSS eggs are small, approximately 0.02 to 0.06 inches ( 0.5 to 1.5 millimeters). Parasitoid larvae pupate within GWSS eggs and then chew circular holes, through which they emerge in search of mates and new host eggs to attack. G. ashmeadi, G. morrilli and G. triguttatus are solitary endoparasitoids that lay one egg per GWSS egg within an egg mass, and the developing larva feeds within this host egg thereby killing it. In contrast and possibly due to its relatively smaller size, G. fasciatus is gregarious, and individual females deposit more than one egg per GWSS egg, yielding multiple parasitoids per host egg (Triapitsyn et al. 2003).

Researchers at UC Riverside have shown that the density of female parasitoids searching for hosts has a significant effect on the sex ratio of progeny produced (Irvin and Hoddle 2005b). When female Gonatocerus parasitoids fail to encounter other ovipositing females of the same species on a GWSS egg mass, progeny output is strongly female-biased. Laboratory experiments indicate that when the female does not encounter a competitor while ovipositing, the ratio of males to females produced is approximately 1 to 8,1 to 14 and 1 to 9 for G. ashmeadi, G. triguttatus and G. fasciatus, respectively. However, increasing the number of ovipositing females of the same species from one to two per egg mass reduces the female offspring produced by up to $15 \%$ for all three Gonatocerus species. These results suggest that local mate competition affects progeny production, and more males are produced when females encounter other females of the same species that are producing daughters with whom their sons might mate.

Laboratory studies where each parasitoid was presented with eggs of 


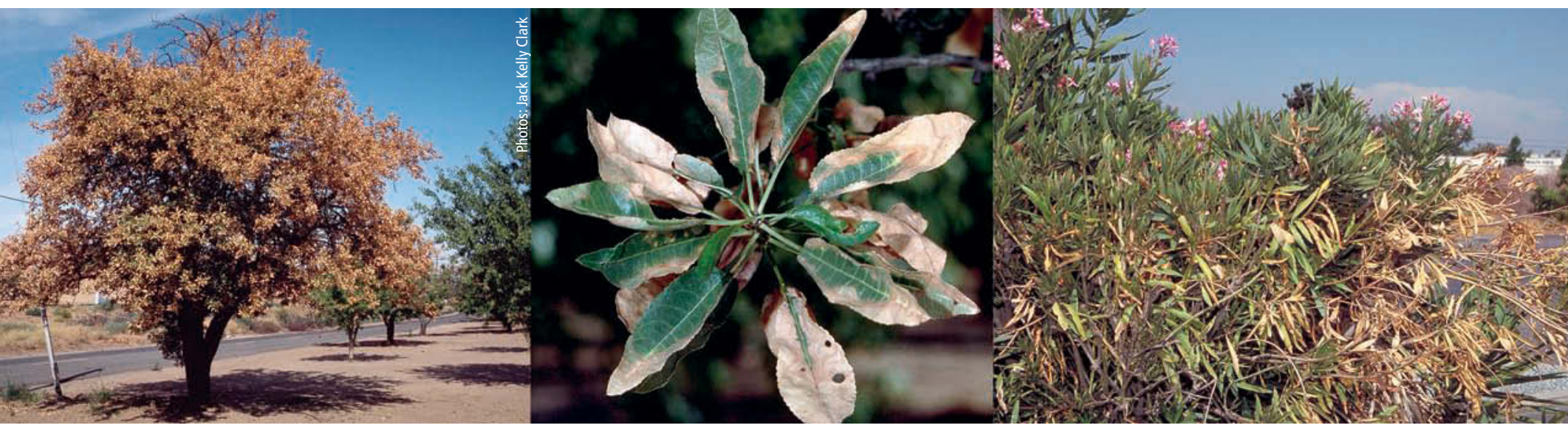

Almond leaf scorch, left and center, is a relatively slow-spreading disease that may take many years to establish in cropping systems. Right, oleander leaf scorch is causing millions of dollars of damage to California's freeway median strips and other ornamental plantings.

a single age showed that progeny production was greatest from GWSS eggs 3, 4 and 2 days old for G. ashmeadi, G. triguttatus and G. fasciatus, respectively. Furthermore, each parasitoid species was able to utilize a range of egg ages around their most preferred age: 1 to 4,3 to 6 , and 1 to 3 days old for G. ashmeadi, G. triguttatus and G. fasciatus, respectively. GWSS eggs that were parasitized at 8 to 10 days of age produced few parasitoid progeny and those that did emerge had been oviposited into sterile or dead host eggs lacking a GWSS embryo (Irvin and Hoddle 2005a). This suggests that the low production of parasitoid progeny in older GWSS eggs was most likely due to the advanced stage of development of the GWSS embryos.

No oviposition preferences were observed when GWSS eggs 1, 3 and 5 days old were presented simultaneously to G. ashmeadi and G. triguttatus. This suggests that these two parasitoids will attack host eggs without preference as long as eggs are of a suitable age for oviposition. These choice studies indicated that G. fasciatus preferred GWSS eggs 1 and 3 days old, while eggs 5 days old were not utilized. The small size of G. fasciatus in comparison to G. ashmeadi and G. fasciatus possibly limits the range of GWSS egg ages available for parasitism. This may occur because the smaller ovipositor of G. fasciatus may be unable to pierce the chorion of older eggs as they harden during maturation.

\section{Field survival and parasitism}

Most agricultural environments are unfavorable habitats for natural enemies. Herbicides can remove shelter and floral resources that biological control agents depend on, and pesticide residues can kill biological control agents (Gurr et al. 2003). UC Riverside scientists have demonstrated that compared to plain water, providing honey-water and flowers of buckwheat (Fagopyrum esculentum Moench) significantly increased the longevity of both male and female G. ashmeadi, G. triguttatus and G. fasciatus up to $94.6 \%, 92.4 \%$ and $93.1 \%$, respectively. These results indicate that resource procurement may be extremely important for enhancing parasitoid survival in agroecosystems. However, this assertion is speculative until extensive field experimentation is undertaken. Since resource procurement increases the longevity of female parasitoids, this may enhance biological control of the GWSS because females that live longer may encounter more GWSS egg masses and consequently parasitize more eggs.

UC Riverside scientists have also shown that the longevity of G. ashmeadi, G. triguttatus and G. fasciatus feeding on citrus flowers and GWSS excrement was equivalent to that on water. This indicates that these field resources may not supply parasitoids with adequate nutrition to maximize survival. One potential way to enhance parasitoid populations, and consequently increase the efficacy of pest control by natural enemies in agricultural systems, is understory management or the deliberate management of flowering plants beneath orchards and vineyards (Landis et al. 2000). Sowing flowering plants (such as buckwheat, dill [Anethum graveolens L.] or alyssum [Lobularia maritima L.]) as an understory could potentially provide a food source to Gonatocerus spp. and increase GWSS biological control. The UC Riverside researchers found that survival times for both sexes of G. ashmeadi, G. triguttatus and G. fasciatus increased by up to $85.2 \%$ with softscale (Coccus hesperidum L.) excrement than with citrus foliage alone, suggesting that in citrus orchards nondamaging levels of softscale may also be beneficial for enhancing parasitoid survival and could enhance biological control of GWSS.

\section{Invasive potential of GWSS}

GWSS has shown strong invasive potential, having become established in a variety of places outside its native range, including California, French Polynesia and Hawaii. Modeling that combines regional climate data and relevant biological information indicates that California's premier wine-growing areas of Napa, Sonoma and Mendocino counties are vulnerable to invasion by GWSS (Hoddle 2004a). In contrast, states north of California, which also have substantial grape industries, may be too cold to harbor permanent popu- 
lations. Other climates conducive to GWSS invasion - should it be accidentally introduced - include the major wine-growing regions of New Zealand, Australia, the Bordeaux region of France, most areas of Spain, and central and southern Italy (Hoddle 2004a).

Data on GWSS in Tahiti is sobering. Populations of this pest grew exponentially because there is an abundance of suitable native and exotic host plants; the mild climate permits year-round breeding (in contrast to California, where there are just two generations, spring and summer, each year); and natural enemies are lacking, while no obvious competitors exist in urban or natural settings. Naturally occurring parasitism of GWSS eggs is very low on the French Polynesian island of Mo'orea. UC surveys indicated that less than $2 \%$ of total GWSS eggs were attacked by parasitoids (table 1).

The wasp that attacked these GWSS egg masses is a platygasterid, a family that does not specialize on sharpshooters but will parasitize various species of leafhoppers. The data on parasitism in Tahiti indicates that there are no specialized parasitoids attacking GWSS. Only a few eggs in an egg mass are attacked, indicating inefficient and opportunistic exploitation, and only males were reared from GWSS eggs, suggesting poor host quality because females did not oviposit fertilized eggs that yield female offspring. This data clearly indicates that GWSS populations in French Polynesia are free of the pressures associated with natural enemies. A classical biological control initiative against GWSS has been launched and is a cooperative enterprise between UC Riverside, UC Berkeley and the French Polynesian government.

\section{Natural enemies and IPM}

GWSS is a major pest in California because of its ability to vector Xylella, and the invasive potential of this pest has been clearly demonstrated by its establishment in French Polynesia, Hawaii and Easter Island. In all invaded areas,

\begin{tabular}{|c|c|c|c|c|}
\hline $\begin{array}{l}\text { GWSS eggs } \\
\text { examined }\end{array}$ & $\begin{array}{l}\text { GWSS eggs } \\
\text { parasitized }\end{array}$ & $\begin{array}{l}\text { GWSS eggs } \\
\text { eaten }\end{array}$ & $\begin{array}{l}\text { GWSS that died } \\
\text { of natural causes* }\end{array}$ & $\begin{array}{l}\text { GWSS eggs from } \\
\text { which nymphs emerged }\end{array}$ \\
\hline $\begin{array}{l}2,586 \text { (246 egg } \\
\text { masses studied) }\end{array}$ & 32 & 444 & 50 & 2,060 \\
\hline$\%$ of eggs & 1.24 & 17.17 & 1.93 & 80 \\
\hline
\end{tabular}

biological control with host-specific mymarid egg parasitoids appears to be the only feasible control strategy for providing long-term, area-wide suppression of this pest. This is a challenging problem because, in agriculturally dependent areas such as California, even excellent biological control of GWSS may not be sufficient to reduce substantial crop losses caused by Xylella vectored by GWSS. In this instance, natural enemies must form the cornerstone of integrated pest management programs for GWSS.

L.J. Pilkington and N.A. Irvin are Postdoctoral Scholars, E.A. Boyd is Ph.D. Candidate, M.S. Hoddle is Extension Specialist in Biological Control, S.V. Triapitsyn is Principal Museum Scientist, and B.G. Carey is Staff Research Associate, all with the Department of Entomology, UC Riverside; W.A. Jones is Director, USDA-ARS European Biological Control Laboratory, Montpellier, France; and D.J.W. Morgan is Entomologist, CDFA Mount Rubidoux Field Station, Riverside.

\section{References}

[CDFA] California Department of Food and Agriculture. 2003. Pierce's disease control program - report to the legislature, May 2003. www.cdfa.ca.gov/phpps/pdcp/docs/ 2002LegReport.pdf (accessed July 8, 2004).

CDFA. 2005. Pierce's Disease Geographic Information System. http://max.cdfa.ca.gov/ pdcp-gis/pdcp-gis.asp

Cheou D. 2002. Incursion of glassy winged sharpshooter Homalodisca coagulata in French Polynesia. Plant Protection Service Pest Alert:1.

Costa HS, Blua MJ, Bethke JA, Redak RA. 2000. Transmission of Xylella fasitidiosa to oleander by the glassywinged sharpshooter, Homalodisca coagulata. HortSci 35(7):1265-7.

Gurr GM, Wratten SD, Luna JM. 2003. Multi-function agricultural biodiversity: Pest management and other benefits. Basic Applied Ecol 4(2):107-16.
Hoddle MS. 2004a. The potential adventive geographic range of glassy-winged sharpshooter, Homalodisca coagulata and the grape pathogen Xylella fastidiosa: Implications for California and other grape growing regions of the world. Crop Prot 23:691-9.

Hoddle MS. 2004b. Restoring balance: Using exotic natural enemies to control invasive exotic species. Cons Biol 18:38-49.

Hoover W. 2004. New invader may threaten crops. Honolulu Advertiser, May 14.

Irvin N, Hoddle MS. 2005a. Determination of Homalodisca coagulata (Hemiptera: Cicadellidae) egg ages that are suitable for oviposition by Gonatocerus ashmeadi, G. triguttatus and G. fasciatus (Hymenoptera: Mymaridae): (1) no choice tests. Biol Control 32:391-400.

Irvin NA, Hoddle MS. 2005b. The competitive ability of three mymarid egg parasitoids (Gonatocerus spp.) for glassy-winged sharpshooter (Homalodisica coagulata) eggs. Biol Control 34:204-14.

Landis DA, Wratten SD, Gurr GM. 2000. Habitat management to conserve natural enemies of arthropod pests in agriculture. Ann Rev Entomol 45:175-201.

Siebert J. 2001. Economic impact of Pierce's disease on the California grape industry. California Department of Food and Agriculture Pierce's Disease Research Symposium. p 111-6.

Sorensen JT, Gill RJ. 1996. A range extension of Homalodisca coagulata (Say) (Hemiptera: Clypeorrhyncha: Cicadellidae) to southern California. Pan-Pacific Entomol 72(3):160-1.

Triapitsyn SV, Morgan DJW, Hoddle MS, Berezovskiy VV. 2003. Observations on the biology of Gonatocerus fasciatus Girault (Hymenoptera: Mymaridae), egg parasitoid of Homalodisca coagulata (Say) and Oncometopia orbona (Fabricius) (Hemiptera: Clypeorrhyncha : Cicadellidae). Pan-Pacific Entomol 79(1):75-6.

Triapitsyn SV, Phillips PA. 2000. First record of Gonatocerus triguttatus (Hymenoptera: Mymaridae) from eggs of Homalodisca coagulata (Homoptera: Cicadellidae) with notes on the distribution of the host. Florida Entomol 83(2):200-3.

Vickerman DB, Hoddle MS, Triapitysn SV, Stouthamer R. 2004. Species identity of geographically distinct populations of the glassywinged sharpshooter parasitoid Gonatocerus ashmeadi: Morphology, DNA sequences and reproductive compatibility. Biol Control 31:338-45. 